\title{
PERBEDAAN LITERASI EMERGEN ANAK TAMAN KANAK-KANAK DI DAERAH PERKOTAAN DAN PINGGIRAN
}

\author{
Tri Puji Astuti
}

\author{
Fakultas Psikologi Universitas Diponegoro \\ J1. Prof. Sudharto SH, Tembalang, Semarang 50275 \\ pujiasjur@gmail.com
}

\begin{abstract}
The aim of this study is to describe the development of emergent literacy in kindergarten children and to compare the development of emergent literacy of kindergarten children in the urban and sub urban area of Semarang city. In order to collect data, the Emergent Literacy developmental Test was used (part of the test was adapted from the Get Ready To Read by Whitehurst). In total, 36 children aged 4-5 years participated in the study. The results showed that kindergarten children from urban area scored higher significantly $(13.188 \pm 3.43)$ in the emergent literacy than children from sub urban area $(10.00 \pm 3.146 ; t(35)=2.903 ; p=0.003)$.
\end{abstract}

Keywords: emergent literacy, kindergarten, preschool, urban, sub urban, Semarang

\begin{abstract}
Abstrak
Tujuan dari peneltian ini adalah untuk memberikan gambaran perkembangan literasi emergen pada anak TK dan perbedaan perkembangan literasi emergen anak TK yang berada di daerah perkotaan dan pinggiran wilayah Semarang. Alat pengumpul data yang digunakan adalah Tes Perkembangan Literasi Emergen yang sebagian mengadopsi dari alat Get Ready To Read dari Whitehurst. Subjek penelitian berjumlah 36 anak berumur antara 45 tahun. Hasil penelitian menunjukkan perbedaan perkembangan literasi emergen pada anak di kedua sekolah (TK) tersebut. Anak TK di wilayah perkotaan menunjukkan skor literasi emergen lebih tinggi $(13,188 \pm 3,43)$ dibanding dengan anak TK di wilayah pinggiran $(10,00 \pm 3,146 ; t(35)=2,903 ; p=0,003)$.
\end{abstract}

Kata kunci: literasi emergen, prasekolah, perkotaan, pinggiran, Semarang

\section{PENDAHULUAN}

Menurut Reese, Garnier, Gallimore, dan Goldenberg (2000) pengalaman anak berinteraksi dengan literasi sejak dini akan menyiapkan mereka mengikuti pembelajaran di sekolah formal. Anak yang sudah menguasai kemampuan literasi sejak dini akan menyebabkan anak menjadi seorang pembelajar sepanjang hidupnya (Bruns \& Pierce, 2007).

Kemampuan literasi tidak sama dengan kemampuan menulis dan membaca pada umumnya, meskipun hasil akhir dari pembelajaran literasi sejak dini adalah kemampuan tersebut. Oleh karena itu pendekatan literasi emergen membedakan kemampuan literasi yang konvensional dengan kemampuan literasi yang dimiliki anak usia dini. Pendekatan tersebut menyatakan bahwa stimulasi untuk mengembangkan kemampuan literasi sebaiknya dimulai sejak dini, karena anak selalu dalam proses menjadi terliterasi (Soderman, Gregory \& McCarty, 2005; Tracey \& Morrow, 2006).

Semua perilaku yang berhubungan dengan literasi misalnya permainan mengubah bunyi-bunyi dalam suatu kata, perilaku membaca pura-pura, membuat coretan, 
melihat tulisan di majalah, label ataupun iklan akan muncul pada masa-masa pra sekolah sebagai aspek yang penting dalam proses perkembangan literasi awal. (Whitehurst \& Lonigan, 2001). Perilaku yang ditampilkan tersebut merupakan dasar untuk mengembangkan kemampuan literasi yang konvensional (Justice \& Kaderavek, 2002).

Menurut Whitehurst dan Lonigan (1998), literasi emergen merupakan perkembangan ketrampilan, pengetahuan dan perilaku yang mendasari membaca dan menulis. Brito, Fuligni, \& Gunn, (2006), Papalia, Olds, \& Feldman (2001), Whitehurst \& Lonigan (2001), menyatakan literasi emergen terdiri dari dua set ketrampilan dan proses, yaitu inside-out dan domain outside-in. Domain inside-out merupakan pengetahuan tentang aturan-aturan atau cara mentransformasikan tulisan ke bentuk suara dan suara ke bentuk tulisan. Domain outside-in merupakan sumber informasi yang berasal dari luar tulisan yang mengarahkan pemahaman terhadap makna tulisan misalnya: kosa kata, pengetahuan konsepsual, dan skema cerita. Kedua proses tidak dapat dipisahkan saat anak memasuki sekolah dasar kelas tiga (Lonigan, 2006). Pada anak-anak, atau pembaca yang belum berpengalaman domain inside-out lebih berperan, karena saat itu dibutuhkan ketrampilan untuk mengidentifikasikan fonem, huruf dan kata. Sedangkan domain outside-in menjadi penting dalam masa pembelajaran membaca yang bertujuan memahami isi dan makna tulisan yang dibaca.

Menurut Bjorklund (2005), sebagian besar anak sudah mempelajari tentang membaca sebelum mereka benar-benar mampu membaca. Anak sudah mengetahui bahwa tulisan dan bahasa ucapan mempunyai hubungan serta mempunyai makna tertentu. Anak usia pra sekolah sebenarnya belum dikategorikan benar-benar mampu membaca. Mungkin saja mereka mampu mengidentifikasikan simbol merk suatu produk ketika melihatnya, akan tetapi perilaku tersebut sesungguhnya bukan membaca.

Berbagai cara dapat dilakukan untuk melancarkan proses tersebut meliputi penciptaan lingkungan yang sering memfungsikan bahasa dan literasi termasuk lingkungan yang membiasakan penggunaan tulisan dalam aktivitas, interaksi antara anak dan orang dewasa, dan dikembangkannya kegiatan yang menyertakan membaca buku bersama. Menurut Lonigan, Anthony, Bloomfield, Dyer, dan Samwel (1999) deteksi awal kemampuan literasi anak akan memberikan informasi resiko kesulitan membaca anak dan gangguan perilaku anak misalnya gangguan pemusatan perhatian. Ada berbagai macam cara dan alat ukur untuk mengetahui perkembangan literasi emergen, ada yang mengukur secara terpisah domain-domain dari literasi emegen, misalnya penelitian dari Whitehurst dan Lonigan (1998), yang membedakan domain literasi emergen menjadi berbagai komponen pengetahuan dan ketrampilan yang masing-masing alat ukur untuk mengetahui kemampuan tersebut dibuat oleh beberapa ahli yang berbeda.

Di tahun 2001 Whitehurst dan Lonigan, menggunakan alat ukur Get Ready To Read untuk mengevaluasi kemampuan literasi emergen, dan alat tersebut mempunyai nilai reliabilitas sebesar 0.8. Sedangkan Lonigan, Burgess dan Anthony (2000), mengukur kemampuan literasi emergen pada aspek pengetahuan huruf dan kepekaan fonologis. Molfese, Modglin, Beswick, Neamon, Berg, Berg, \& Molnar (2006) dalam penelitiannya juga menggunakan alat asesment Get Ready to Read untuk mengukur kemampuan literasi emergen. Alat ukur tersebut berkorelasi Developing Skills Checklist yaitu alat 
untuk mengetahui aspek-aspek perkembangan sosial dan emosional, ketrampilan personal, kemampuan komunikasi dan bahasa, kemampuan matematika, membaca dan motorik halus. Alat ukur Get Ready To Read menjadi pilihan beberapa ahli untuk mengukur perkembangan dan ketrampilan literasi emergen karena beberapa pertimbangan yaitu waktu yang singkat, memakai media yang disukai anak yaitu gambar dan mengukur bermacam-macam aspek dalam domain literasi emergen (Farver, Nakamoto, \& Lonigan, 2007; Invernizzi, Landrum, Teichman, \& Townsend, 2010; Wilson \& Lonigan, 2009). Dari beberapa kali penelusuran, penelit belum menemukan artikel penelitian yang menggunakan alat tes Get Ready to Read untuk mengetahui perkembangan literasi awal pada anak-anak di Indonesia. Untuk itulah, sebagai penelitian awal alat tersebut perlu dicobakan untuk anak Indonesia.

Hasil penelitian diatas menunjukkan bahwa alat ukur Get Ready to Read banyak menjadi pilihan untuk dijadikan skrining mengases anak yang perkembangan literasi emergennya lebih maju. Alat ukur tersebut juga dapat membedakan anak-anak yang kurang mendapatkan stimulasi, misalnya subjek yang berasal dari ekonomi dan lingkungan yang kurang mendukung. Dijelaskan oleh Gonzalez, Goetz, Hall, Payne,Taylor, Kim, \& McCormick, (2009) bahwa salah satu alasan perlunya intervensi pada keluarga yang digolongkan sebagai berpenghasilan rendah karena biasanya keluarga tersebut kurang memberikan dukungan untuk pemenuhan rangsangan pembelajaran yang berkaitan dengan literasi. Dari pembahasan studi oleh Friend, dkk. (2009) diterangkan bahwa lingkungan keluarga yang mendukung anak-anaknya untuk belajar di sekolah dengan memberikan kesempatan untuk belajar di rumah, akan meminimalkan kemungkinan akibat dari pengaruh genetis yang kurang menguntungkan. Pendidikan orang tua, kebiasaan orang tua membaca, dan aktivitas membacakan buku dianggap mewakili sebagai lingkungan yang positif yang akan memudahkan anak belajar literasi di rumah.

Durham \& Smith, (2006), mengatakan bahwa ada hubungan langsung antara lingkungan non metropolitan dengan kemampuan literasi awal pada anank-anak di awal taman kanak-kanak. Akan tetapi arah dan kekuatan hubungan tersebut tergantung dari status sosial ekonomi serta karakteristik lingkungan sosial ekonomi dari daerah tersebut. Daerah non perkotaan yang beresiko terhadap perkembangan literasi awal anak adalah yang mempunyai keluarga berpenghasilan rendah dan tidak tetap, banyak penduduk yang putus sekolah, dan pengangguran. Ditambahkan oleh Ayouba, O'Connorb, Rappolt-Schlictmann, Vallottond, Raikese, \& Chazan-Cohenf, R. (2009), bahwa anak yang tumbuh dalam situasi kemiskinan mempunyai resiko perkembangan kognitif yang kurang dibandingkan rata-rata. Selain itu, anakanak yang tumbuh di keluarga yang mendapatkan tunjangan kemiskinan dari pemerintah, ibu yang berpendidikan rendah (di bawah pendidikan menengah), kurangnya stimulasi kognitif dan bahasa di rumah dan anak-anak yang secara emosional kurang berkembang penurunan skor kemampuan kognitif akan semakin cepat. Karaktersitik lain dari anak-anak yang kemampuan kognitifnya mengalami kemunduran apabila mereka tinggal di keluarga yang mendapatkan tunjangan kemiskinan dari pemerintah dan yang orang tuanya tidak bekerja serta ibu yang mempunyai pendidikan rendah.

Dari pertimbangan bukti penelitian telah dipaparkan sebelumnya maka penelti ingin menggambarkan perbedaan perkembangan literasi emergen pada anak yang berasal dari dua lingkungan yang berbeda yaitu lingkungan yang kaya dengan lliterasi dan lingkungan yang kurang memberikan 
stimulasi yang berkaitan dengan literasi. Lingkungan yang kaya literasi direpresentasikan pada TK yang berada di daerah perkotaan yang dikelola oleh swasta. Sedangkan lingkungan yang kurang mendukung pemberian stimulasi diwakili oleh TK yang ada di pinggiran kota. Karakteristik daerah pinggiran yang dijadikan wilayah penelitian berdasarkan studi dari Sarbidi (2011).

\section{METODE}

\section{Alat Ukur}

Alat pengumpul data yang digunakan adalah Tes Perkembangan Literasi dasar untuk membuat gambar dan pertanyaan yang disesuaikan kaidah bahasa Indonesia. Sebelum digunakan, peneliti melakukan peer judgment pada anak usia dini yang bukan menjadi subjek penelitian dan profesional judgment dari beberapa kader serta pendidik anak usia untuk mengetahui apakah alat yang digunakan sudah sesuai dengan tujuan pengukuran.

Cara menyajikan instrumen ini dilakukan satu persatu dengan anak secara individual, yaitu anak diperlihatkan empat gambar pada setiap nomernya kemudian diminta untuk menjawab pertanyaan tester. Misalnya pada pertanyaan nomer 7 , tester akan bertanya "yang mana huruf L pada

Tabel 1.

Tes Perkembangan Literasi Emergen

\begin{tabular}{|c|c|c|c|c|}
\hline Domain & Unit & Ketrampilan & Bentuk & $\begin{array}{l}\text { No } \\
\text { aitem }\end{array}$ \\
\hline \multirow[t]{8}{*}{ Inside-Out } & \multirow{4}{*}{$\begin{array}{l}\text { Unit } \\
\text { Bunyi/Ke- } \\
\text { sadaran } \\
\text { Fono } \\
\text { logis }\end{array}$} & $\begin{array}{l}\text { Macthing bunyi / } \\
\text { suku kata }\end{array}$ & $\begin{array}{l}\text { Intruksi untuk memilih gambar yang bunyi } \\
\text { depannya sesuai dengan kata target }\end{array}$ & 14,15 \\
\hline & & $\begin{array}{l}\text { Identifikasi bunyi / } \\
\text { suku kata berima }\end{array}$ & $\begin{array}{l}\text { Instruksi untuk memilih gambar yang bunyi } \\
\text { belakangnya berima dengan kata target }\end{array}$ & 16 \\
\hline & & $\begin{array}{l}\text { Addition/Substitution } \\
\text { bunyi / suku kata }\end{array}$ & $\begin{array}{l}\text { Instruksi untuk memilih gambar yang } \\
\text { namanya merupakan bentukan baru suatu } \\
\text { suku kata }\end{array}$ & $\begin{array}{l}17,18 \\
19\end{array}$ \\
\hline & & $\begin{array}{l}\text { Deletion bunyi / suku } \\
\text { kata }\end{array}$ & $\begin{array}{l}\text { Instruksi untuk memilih gambar yang suku } \\
\text { kata depannya dihilangkan }\end{array}$ & 20 \\
\hline & \multirow[t]{4}{*}{$\begin{array}{l}\text { Unit } \\
\text { tulisan }\end{array}$} & $\begin{array}{l}\text { Pengetahuan tentang } \\
\text { huruf }\end{array}$ & Instruksi untuk memilih huruf yang diminta & 6,7 \\
\hline & & $\begin{array}{l}\text { Hubungan huruf- } \\
\text { suara }\end{array}$ & $\begin{array}{l}\text { Instruksi untuk huruf yang memiliki bunyi } \\
\text { tertentu }\end{array}$ & $8,9,10$ \\
\hline & & Tulisan emergen & $\begin{array}{l}\text { Instruksi untuk mengidentifikasi tulisan } \\
\text { yang baik. }\end{array}$ & $\begin{array}{l}11,12 \\
13\end{array}$ \\
\hline & & Konsep tulisan & $\begin{array}{l}\text { Instruksi untuk mengidentifikasikan } \\
\text { karakteristik suatu buku }\end{array}$ & $\begin{array}{l}1,2,3 \\
4,5\end{array}$ \\
\hline Outside-in & & Kosa kata & $\begin{array}{l}\text { Bahasa ekspresif dan reseptif yang dikuasai } \\
\text { melalui gambar dan anak diminta untuk } \\
\text { menyebutkan namanya }\end{array}$ & Latihan \\
\hline
\end{tabular}

Emergen. Tes Perkembangan Literasi Emergen ini sebagian mengadopsi dari alat Get Ready To Read dari Whitehurst (2001). The Get Ready to Read bahasa Indonesia terdiri dari 20 aitem. Peneliti menggunakan aspek-aspek pada alat tes tersebut sebagai gambar ini? Anak diminta menjawab pertanyaan dengan menunjuk pada gambar tersebut. Aspek-aspek perkembanga literasi emergen yang diukur dengan aitem-aitem tersebut adalah pengetahuan tentang tulisan, yang dimasukkan pada domain 
inside-out terdiri dari 13 aitem konsep tentang tulisan, pengetahuan huruf, bentuk tulisan, serta kesadaran fonologis sebanyak 7 aitem. Sedangan domain outside-in yang berupa kosa kata diberikan sebagai tes awal untuk latihan. Aspek-aspek perkembangan literasi emergen dan aitem-aitemnya dirangkum pada Tabel 1. Reliabilitas konsistensi internal pada instrumen berbahasa Inggris adalah 0,78, sedangkan pada penelitian ini sebesar 0,67 .

\section{Subjek Penelitian}

Subjek penelitian yang dilibatkan pada penelitian ini berjumlah 36 anak yang terdiri berusia antara $4-5$ tahun, dari dua TK di Wilayah Semarang. Anak perempuan berjumlah 19 orang dan anak laki-laki berjumlah 17 orang. Dari TK yang berlokasi di Semarang Utara (wilayah pinggiran) berjumlah 16 anak, sedangkan TK yang berlokasi di Semarang Selatan (wilayah perkotaan) berjumlah 20 anak.

Secara umum, kedua TK tersebut memberikan fasilitas yang hampir sama yang berkaitan dengan media literasi. Kelebihan yang didapatkan anak di TK Semarang Selatan adalah mereka diajarkan komputer dan ada pelajaran khusus menggambar. Wlayah Semarang Selatan yang cenderung lebih nyaman (karena tidak terkena banjir) lebih memungkinkan anakanaknya mengeksplorasi lingkungan dengan bebas. Mereka terlihat lebih asertif dan mempunyai keberanian untuk berinteraksi dengan orang asing. Akan tetapi peneliti tidak mengalami kesulitan untuk melakukan pendekatan dan asesmen pada anak-anak tersebut. Sebagian besar mereka terlihat kooperatif dan bersedia diwawancarai oleh peneliti. Perbedaan yang menonjol terlihat pada karakteristik keluarga subjek penelitian. Sebagian besar orang tua di TK Semarang Selatan berpendidikan diatas Sekolah menengah dan status pekerjaan yang lebih mapan.
Sebagai sekolah yang dikelola swasta, pihak pengurus sekolah mempunyai kesempatan untuk mengembangkan fasilitas sekolah dengan dana yang lebih besar.

Sedangkan di TK Semarang Utara, sebagian besar orang tua anak berpendidikan Sekolah Menengah dan mempunyai pekerjaan tidak tetap. Selain itu, mereka memlih memasukkan anaknya di TK tersebut karena tidak dipungut biaya yang besar, karena pengelolaan dana disubsidi dari pemerintah daerah. Menurut keterangan dari guru keterllibatan orang tua terhadap kegiatan sekolah kurang maksimal. Mereka memasukkan anaknya ke sekolah agar anak-anak tidak berkeliaran di jalanan. Pihak pengurus sekolah tidak dapat menggantunggkan penyediaan fasilitas sekolah dari orang tua anak.

\section{HASIL DAN PEMBAHASAN}

Sebelum dianalisis statistik, terlebih dahulu akan diperlihatkan skor perkembangan literasi emergen pada masing-masing TK yang disajikan dalam Tabel 2. Dari datadata tersebut kemudian dianalisis statistik uji beda antara dua sekolah yang menjadi tempat penelitian yang memperlihatkan hasil pada Tabel 3 .

Dari analisis statistik didapatkan ada perbedaan rerata pada kedua kelompok sebesar 3,19; $p=0,003$ dengan $t_{\mathrm{e}}=2,903$. Rerata perkembangan literasi untuk kelompok pertama (pinggiran) sebesar 10,00 dan kelompok kedua (perkotaan) 13,19. Hasil analisis data tersebut menunjukkan bahwa skor perkembangan literasi emergen pada kelompok kedua lebih tinggi dibanding kelompok pertama, perbedaan skor perkembangan literasi emergen tersebut dikatakan signifikan. 
Tabel 2.

Statistik Deskriptif Perbedaan Perkembangan Literasi Emergen

\begin{tabular}{lcccccc}
\hline Kelompok & Jumlah & Rerata & SD & Perbedaan rerata & $\boldsymbol{t}$ & Sig. \\
\hline TK Pinggiran (1) & 20 & 10,000 & 3,146 & $-3,188$ & 2,903 & 0,003 \\
TK Perkotaan (2) & 16 & 13,188 & 3,430 & & & \\
\hline
\end{tabular}

Dari gambaran data yang disajikan dalam Tabel 3 terlihat bahwa rata-rata subjek menyelesaikan tes tersebut dalam waktu 9,2 menit untuk anak-anak di salah satu TK di pinggiran, dan anak mampu menjawab dengan benar sebanyak rata-rata 10 soal. Anak-anak yang ada di salah satu TK di perkotaan menyelesaikan tes dalam waktu 9 menit 3 detik dengan jawaban benar sebanyak 13. Tes yang biasa dipergunakan di negara-negara USA dan Eropa, membutuhkan waktu 10 menit untuk pengadministrasiannya dengan jumlah tes 25 aitem. Sedangkan di Indonesia rata-rata anak mampu menjawab dalam waktu 10 menit untuk jumlah soal sebanyak 20.

Aitem-aitem yang sulit dijawab oleh anakanak TK tersebut adalah no 1,2 yaitu subtes yang mengukur kemampuan anak untuk mengidentifikasi karakterisk buku dan mengidentifikasi huruf serta tulisan yang ada di konteks atau yang menempel pada fungsi tulisan yang dinamakan sebagai print environment. Sedangan aitem no 16 merupakan subtes yang mengukur kemampuan anak mengidentifikasikan rima dalam suatu kata. Kemampuan ini

Tabel 3.

Data Deskriptif Subjek Penelitian

\begin{tabular}{llrrllrrr}
\hline \multicolumn{4}{c}{ Daerah Pinggiran } & \multicolumn{5}{c}{ Daerah Perkotaan } \\
\hline No & JK & Waktu & Total Benar & No & JK & Waktu & Total Benar \\
\hline 1 & $\mathrm{P}$ & 9.02 & 14 & 1 & $\mathrm{P}$ & 6.48 & 9 \\
2 & $\mathrm{P}$ & 11.05 & 10 & 2 & $\mathrm{P}$ & 9.01 & 18 \\
3 & $\mathrm{P}$ & 11.05 & 7 & 3 & $\mathrm{P}$ & 9.13 & 16 \\
4 & $\mathrm{P}$ & 9.20 & 9 & 4 & $\mathrm{~L}$ & 8.20 & 7 \\
5 & $\mathrm{P}$ & 8.16 & 10 & 5 & $\mathrm{~L}$ & 9 & 15 \\
6 & $\mathrm{P}$ & 7.15 & 13 & 6 & $\mathrm{~L}$ & 8.32 & 14 \\
7 & $\mathrm{P}$ & 9.23 & 7 & 7 & $\mathrm{~L}$ & 9.09 & 14 \\
8 & $\mathrm{P}$ & 7.32 & 8 & 8 & $\mathrm{~L}$ & 11.51 & 6 \\
9 & $\mathrm{P}$ & 9 & 12 & 9 & $\mathrm{~L}$ & 6.16 & 11 \\
10 & $\mathrm{P}$ & 8.53 & 8 & 10 & $\mathrm{~L}$ & 6.30 & 14 \\
11 & $\mathrm{~L}$ & 10 & 8 & 11 & $\mathrm{~L}$ & 8.56 & 16 \\
12 & $\mathrm{~L}$ & 9.28 & 14 & 12 & $\mathrm{~L}$ & 8 & 15 \\
13 & $\mathrm{~L}$ & 10.02 & 16 & 13 & $\mathrm{~L}$ & 16.10 & 11 \\
14 & $\mathrm{~L}$ & 11.38 & 3 & 14 & $\mathrm{~L}$ & 15.38 & 16 \\
15 & $\mathrm{P}$ & 8.3 & 10 & 15 & $\mathrm{~L}$ & 10.12 & 15 \\
16 & $\mathrm{P}$ & 11 & 11 & 16 & $\mathrm{~L}$ & 7.43 & 14 \\
17 & $\mathrm{P}$ & 9.05 & 8 & & & & \\
18 & $\mathrm{P}$ & 6.55 & 12 & & & & \\
19 & $\mathrm{P}$ & 9.06 & 7 & & & & \\
20 & $\mathrm{P}$ & 9.03 & 13 & & & &
\end{tabular}


kemungkinan bukanlah prediktor yang baik untuk mengukur perkembangan literasi emergen bagi anak-anak di kedua TK tersebut

Literasi emergen merupakan konsep yang mendukung pembelajaran membaca dalam suasana lingkungan rumah yang kondusif pada waktu anak dalam proses menjadi terliterasi (melek huruf). Perkembangan literasi sudah dimulai pada saat pertama kali anak mulai mendengar cerita dan sajak anak-anak. Perkembangan literasi emergen merupakan proses pendahulu dari aktivitas membaca dan menulis yang dipahami luas sebagai perilaku membaca yang konvensional. Dengan kata lain literasi emergen bukanlah aktivitas membaca dan menulis yang sebenarnya.

Dalam literasi emergen ada berbagai ketrampilan, pengetahuan, dan sikap yang mendukung pembelajaran membaca dan menulis ketika anak memasuki masa sekolah dan mendapatkan pembelajaran membaca secara formal. Oleh karena itu beberapa ahli memandang ketrampilan, pengetahuan dan sikap tersebut sebagai pilar pembentuk atau fondasi kemampuan membaca dan menulis. Anak yang mempunyai fondasi atau pilar pembentuk perilaku membaca dan menulis yang kuat akan memudahkan dirinya menghadapi pembelajaran di kelas. Anak akan lebih cepat menguasai ketrampilan membaca dan menulis dibandingkan dengan anak-anak lain yang tidak mendapatkan stimulasi tersebut. Jadi pada dasarnya pondasi atau pilar tersebut sebagai literasi emergen terdiri atas beberapa ketrampilan, pengetahuan, dan sikap yang dapat meningkatkan pemahaman anak terhadap dunia tulisan. Ketrampilan yang dianggap memiliki kontribusi yang paling besar pada kesiapan anak untuk belajar membaca dan menulis antara lain: kesadaran fonologis, pengetahuan tentang alphabet, kesadaran akan tulisan (Tracey \& Morrow, 2006).
Kesadaran fonologis adalah kepekaan terhadap struktur bunyi dalam suatu bahasa. Kepekaan tersebut akan mengarahkan anak untuk mengasah kemampuan mendeteksi dan memanipulasi struktut bunyi dari bahasa tulisan. Kesadaran fonologis menuntut anak untuk memusatkan perhatian pada bunyi bahasa yang diucapkan, dan untuk sementara mengabaikan artinya. Misalnya ketika anak ditanya mana yang lebih panjang kata kapal dan kata kelelawar, jika anak mempunyai kemampuan untuk memisahkan kata dari artinya akan menjawab kelelawar. Sedangkan anak yang menjawab kapal sebagai kata yang lebih panjang, tidak mempunyai kemampuan tersebut, karena kenyataannya kapal jauh lebih panjang dari kelelawar. Pemahaman bahwa 'kata' sebagai simbol abstrak dan kata sebagai simbol benda konkrit perlu di ajarkan pada anak. Jika anak belum mampu memahami bahwa kata yang diucapkan merupakan rangkaian dari beberapa bunyi huruf, maka mereka sulit memahami mengapa kata kapal lebih pendek dari kelelawar. Anak akan sulit untuk membayangkan kata kapal terdiri dari lima bunyi huruf dan kata kelelewar dibentuk dari sembilan bunyi huruf (Blachman, 2007).

Pemahaman anak bahwa kata dibentuk dari bunyi yang lebih kecil seperti suku kata dan fonem akan membantu 'memecahkan kode' (membayangkan pengucapan kata dengan mempergunakan pengetahuan tentang hubungan sistematik antara bunyi dan huruf) bahasa tulisan dan memperoleh pemahaman mengenai prinsip alphabetik. Prinsip alphabetik merupakan suatu konsep yang menjelaskan bahwa kata yang tertulis merupakan representasi dari kata yang diucapkan melalui hubungan bunyi per bunyi. Bunyi ditandai dengan huruf tunggal atau pada beberapa kasus beberapa huruf menandakan satu bunyi dalam suatu kata (misalnya: sungai, sunyi). Jika guru dan orang tua menyuruh anak untuk 
'menyuarakan' kata yang akan ditulis atau dibacanya, maka perintah tersebut akan berarti apabila anak sudah mempunyai konsep bahwa kata dapat dipecah menjadi komponen yang lebih kecil.

Kesadaran fonologis, pengetahuan huruf dan bunyi huruf tumbuh bersama-sama pada diri anak sehingga dapat digunakan sebagai landasan pemahaman dan memfasilitasi perkembangan membaca dan menulis. Kemampuan tersebut merupakan pemahaman hubungan yang reguler antara huruf dan bunyi untuk membunyikan katakata yang tidak dikenal (Philips, Menchetti, \& Lonigan, 2008). Menurut Stanovich (1986) anak yang tidak mampu melakukan decoding kata pada tahun-tahun pertama di sekolah dasar akan mengalami hambatan untuk menjadi pembaca yang lancar. Anak akan sibuk memusatkan perhatian pada proses tersebut daripada memahami arti kata yang dibacanya. Pada akhirnya anak kurang mendapatkan manfaat dari aktivitas membaca, yaitu untuk menambah perbendaharaan kata dan pengetahuan umum lainnya.

Pada dasarnya untuk mempersiapkan anak menjadi pembaca yang konvensioanal maka ada dua aktivitas yang berperan yaitu ketrampilan memecahkan kode yaitu untuk mengenali huruf, kata dan selanjutnya kalimat, juga ketrampilan untuk memahami arti dari kata dan kalimat yang dibacanya. Untuk mendeteksi ketrampilan-ketrampilan yang mendasari kemampuan membaca konvensional tersebut dibutuhkan suatu alat asesmen yang mudah pengadministrasian. Salah satu alat asesmen perkembangan literasi emergen yang sudah dipakai luas di negara Eropa dan Amerika adalah Get Ready To Read.

Salah satu alasan perbedaan hasil tes Get ready to read dari dua kelompok tersebut sejalan dengan penelitian dari Torr dan Scott (2006) yang mengatakan bahwa perkembangan literasi emergen dapat dipengaruhi oleh perbedaan sosial ekonomi dan keyakinan pembelajaran yang ada di keluarga anak-anak tersebut. Anak yang mempunyai ibu berpendidikan tinggi lebih beruntung daripada anak dengan ibu yang pendidikan rendah, karena biasanya ibu yang berpendidikan rendah kurang tertarik untuk melakukan percakapan yang bertujuan menstimulasi perkembangan literasi baik saat membacakan buku maupun percakapan sehari-hari. Ibu yang berpendidikan rendah biasanya membacakan buku tanpa disertai dengan diskusi tentang arti dari bacaan yang digambarkan oleh ilustrasi dan teks. Sedangkan ibu yang berpendidikan tinggi lebih banyak mengenalkan dan mendiskusikan kosa kata baru yang sifatnya teknis. Selain itu, ibu yang berpendidikan tinggi juga akan menerapkan strategi yang pemberian kesempatan untuk menambah pengetahuan dan konsep anak melalui teks verbal maupun gambar visual.

Sebelumnya, penelitian dari Laakso, Poikkeus, Eklund, dan Lyytinen (2004) menemukan minat anak untuk bermain dengan media literasi juga berhubungan dengan pendidikan ibu. Ibu yang berpendidikan tinggi lebih sadar akan pengaruh positif dari lingkungan rumah yang terliterasi untuk meningkatkan kemampuan bahasa dan literasi emergen anak-anaknya. Kemauan orang tua untuk memberikan pengalaman membaca bersama sebagai mekanisme pelindung untuk menghadapi pengaruh ketidak-beruntungan dikarenakan lingkungan yang tidak mendukung, seperti pada subjek penelitian yang kebetulan tinggal di daerah pinggiran yang lingkungan keluarga dan masyarakat kurang menguntungkan.

Kualitas guru dan lingkungan juga mempengaruhi kualitas perkembangan literasi anak usia dini, kualitas tersebut misalnya penggunaan pembelajaran yang 
berpusat pada anak, penggunaan free play, bermain peran dan pemilihan permainan, serta ada pojok membaca dan menulis yang diefektifkan. Akan tetapi penggunaan materi pembelajaran tersebut harus ada mentoring dan coaching langsung ahli yang dianggap kompeten agar pendidik mendapatkan umpan balik serta ada tempat untuk bertanya ketika menghadapi kesulitan. Tanpa ada bimbingan kader hanya sekedar meniru dan mengulang cara yang sudah dicontohkan. Di sisi lain anak yang terbiasa hanya diberikan pembelajaran dengan mengingat dan meniru, mengalami kesulitan untuk menggunakan metode yang berbeda yang lebih menggunakan kemampuan abstraksi dan verbalisasi, sehingga cenderung mudah bosan (Moorea, Akhterb, \& Abouda, 2008).

Pengetahuan pendidik anak usia dini (PAUD dan TK) pada aktivitas literasi sangat kurang. Perlu program persiapan ketika akan mengajar di di dua jenis tempat tersebut. Jika kebutuhan tersebut tidak dipenuhi maka anak-anak usia dini tidak akan mempunyai kesempatan untuk mendapatkan stimulasi yang memadai tentang literasi awal. Tanpa pelatihan yang cukup, pendidik tidak akan siap untuk mengajar di pendidikan anak usia dini.

Dengan banyaknya anak usia dini yang ikut Paud dan TK, maka akan semakin banyak anak usia dini yang beresiko tidak mendapatkan stimulasi awal untuk literasi (Crim, Hawkins, Rosof, Copley, \& Thomas, 2008). Oleh karena itu pendidik anak usia dini perlu dibekali dengan pengetahuan dan ketrampilan untuk menstimulasi anak usia dini sehingga dapat mempersempit kesenjangan antara anak usia dini yang mendapatkan pelayanan pendidikan yang dianggap berkualitas (misalnya lembaga yang dikelola swasta) dengan anak usia dini dari lembaga pendidikan yang mempunyai pendanaan yang terbatas.
Salah satu hal yang tidak kalah penting adalah melakukan asesmen untuk membedakan anak yang kemungkinan mengalami hambatan perkembang literasi dengan anak yang siap untuk mendapatkan pembelajaran membaca menulis yang konvensional (Farver dkk., 2007). Selain itu asesmen juga di perlukan untuk mengembangkan program intervensi yang tepat apabila anak mengalami hambatan perkembangan literasi emergen (Marvin \& Ogden, 2002). Akan tetapi permasalahan terbesar apabila melakukan asesmen pada anak usia dini adalah karakteristik anak usia dini yang khas yang memerlukan situasi pengetesan tidak seperti aktivitas tes pada umumnya. Inilah yang dinamalan asesment autentik (Bagnato, 2007). Asesmen untuk anak usia dini harus memperhatikan beberapa hal penting misalnya, seting yang menyenangkan, material yang sudah dikenal anak dan menarik serta prosedur yang sederhana. Pada penelitian, karakteristik sudah diperhatikan akan nampaknya perlu ada perhatian yang lebih pada gambar yang digunakan untuk melakukan asesmen misalnya gambar yang dikenal anak dan tidak menimbulkan interpretasi ganda.

Dari hasil analis deskriptif alat yang sama menunjukkan hasil yang berbeda. Perbedaan tersebut antara lain :

a. Aitem 1 dan 2 yang mengukur pengetahuan anak mengenai 'tulisan' yaitu berkaitan perkembangan pemahaman mengenai karakteristik buku dan manfaat buku, kata-kata yang sifatnya tulisan serta huruf, bukanlah prediktor yang baik untuk mengukur perkembangan literasi emergen. Sebagian besar anak salah untuk menjawab aitem tersebut. Mereka tidak dapat membedakan bagian belakang, depan, samping dan dalam buku tersebut, bahkan aitem no.1 merupakan aitem yang paling sulit dijawab baik untuk anak yang mempunyai skor total 
tinggi maupun yang rendah. Aitem no. 2 hanya sepertiga dari subjek penelitian yang menjawab benar. Sedangkan sisanya belum mempunyai pemahaman mengenai konsep tulisan atau karakteristik buku. Aitem ini juga tidak dapat digunakan untuk memprediksi perbedaan perkembangan literasi emergen, karena dianggap mempunyai kesulitan yang cukup tinggi;

b. Aitem no.16 yang berkaitan dengan kemampuan mengidentifikasi suku kata yang berima, nampaknya tidak dapat dijadikan prediktor yang baik karena sebagian besar subjek penelitian menjawab salah. Jadi tingkat kesulitannya juga cukup tinggi. Sejalan dengan hasil penelitian dari Widjaja dan Winskel (2004), subtes kesadaran fonologis yang menggunakan aspek rima, tidak dapat dijadikan dasar untuk mengetahui kemampuan literasi anak di Indonesia. Bagi anak-anak Indonesia, bermain kata-kata dengan menggunakan rima belum banyak digunakan. Kondisi tersebut berbeda dengan pelajaran Bahasa Indonesia di masa lalu yang mengajarkan anaknya bermain dan membuat pantun yang menggunakan rima sebagai dasar pembuatan syairnya.;

c. Aitem no. 5, 6, 8, 10, 11, 15, 17, 18 dan 20 dianggap sebagai subtes yang mudah karena kebanyakan anak menjawab dengan benar. Hanya sebagian kecil dari subjek penelitian yang menjawab salah. Dari hasil tersebut gambaran sementara dari hasil asesmen tersebut adalah subjek penelitian sudah cukup berkembang kemampuan literasi emergen pada aspek pengetahuan tentang huruf dan bunyinya (no. 6, 8, dan 10), serta aitem no.11 mencerminkan kemampuan menulis anak dengan meng-identifikasikan tulisan yang baik diantara tulisan yang dianggap jelek. Khusus untuk aitem no.7 (mengidentifikasi huruf L) dan no. 9 (mengidentifikasi bunyi huruf /ef/) sebagai bagian dari pengetahuan huruf, nampaknya perlu menjadi perhatian khusus, karena pada aitem-aitem tersebut, subjek penelitian yang pada dasarnya sudah lebih berkembang literasi emergennya mampu menjawab dengan benar. Kemungkinan subjek penelitian yang literasi emergennya rendah tetapi menjawab dengan benar, lebih didasarkarkan pada 'perilaku'asal tebak atau bantuan dari teman-temannya. Kondisi tersebut terjadi karena pada saat pengetesan, ruangan yang digunakan tidak sepenuhnya bebas dari gangguan terutama dari subjek penelitian lain yang sudah selesai dites. Aitem no. 15 adalah kemampuan yang berkaitan identifikasi fonem pada suatu kata. Aitem tersebut merupakan soal yang mudah bagi subjek penelitian karena nampaknya stimulus yang disajikan berkaitan dengan bendabenda konkrit yang sudah dikenal dan sering didengar anak. Selain itu, gambar 'angsa' yang ditampilkan diidentifikasi subjek sebagai gambar 'bebek', sehingga anak hanya mengidentifikasi bunyi huruf yang pada tiga aitem saja, bukan empat aitem. Untuk aitem no. 14 yang mengukur kemampuan yang sama tetapi tidak semua subjek mampu menjawabnya nampaknya karena dibandingkan dengan aitem no. 15, gambar yang dijadikan stimulus menampilkan bunyi huruf dan gambar yang khas sehingga anak harus benarbenar paham bunyi huruf masing-masing gambar. Aitem no. 17, 18, dan 20 berkaitan dengan kemampuan kesadaran fonologis. Aitem no. 17 dan 18 anak diminta untuk melakukan 'blending' pada suku kata yang disajikan kemudian harus mengidentifikasi target gambar dari gabungan suku kata tersebut. Sesuai dengan perkembangan kesadaran fonologis bahwa anak-anak dapat mendeteksi atau memanipulasi suku kata sebelum mendeteksi atau memanipulasi fonem. (Anthony \& Francis, 2005) Kondisi inilah yang dapat dijadikan 
landasan untuk menggambarkan karakteristik aitem no. 19, karena anak diminta untuk melakukan 'blending' pada tingkatan fonem. Subjek penelitian yang perkembangan literasi emergennya lebih maju, mampu menjawab aitem tersebut dengan benar. Aitem no. 20 juga berkaitan dengan kemampuan kesadaran fonologis untuk melakukan 'deletion'. Nampaknya tugas tersebut dapat diselesaikan subjek penelitian dengan mudah, karena tugas 'deletion' yang dibuat pada level suku kata, sehingga kabanyakan anak Indonesia lebih memahami ukuran tersebut.;

d. Aitem no. 12 dan 13 berkaitan dengan kemampuan 'menulis'. Kemampuan 'menulis' yang ditampilan pada tes Get Ready To Read! bukan merupakan kemampuan menulis yang diekspresikan dalam bentuk tulisan yang dibuat oleh anak-anak, tetapi lebih pada kemampuan mengidentifikasikan bentuk yang baik dan pemahaman mengenai isi tulisan. Nampaknya anak-anak yang sudah lebih berkembang literasi emergennya mampu menjawab soal tersebut dengan benar. Sedangkan pada anak-anak yang kurang berkembang lebih mudah mengidentifikasi 'kemampuan menulis' tersebut dalam bentuk satu huruf daripada satu kata apalagi satu cerita.

\section{KESIMPULAN}

1. Ada perbedaan kemampuan literasi emergen antara anak-anak yang bersekolah di TK daerah pinggiran dan perkotaan. Kemungkinan perbedaan tersebut disebabkan oleh perbedaan karaktersitik lingkungan yang ada di sekitar sekolah tersebut serta latar belakang sosial ekonomi orangtua anak.

2. Tugas yang berkaitan dengan identifikasi rima tampaknya kurang efektif dijadikan prediktor bagi perkem- bangan literasi emergen anak-anak di Indonesia.

3. Tugas yang berkaitan dengan level suku kata lebih mampu diselesaikan subjek dengan baik daripada tugas yang menggunakan level fonem.

4. Kemampuan menulis lebih menonjol pada anak-anak yang memiliki perkembangan literasi emergen lebih maju.

\section{DAFTAR PUSTAKA}

Anthony, J. L. \& Francis, D. J. (2005). Development of phonological awareness, Current Direction in psychological Science, 14 (5), 255259.

Ayouba, C.. O'Connorb, E., RappoltSchlictmann, G., Vallottond, C., Raikese, H., \& Chazan-Cohenf, R. (2009). Cognitive skill performance among young children living in poverty: Risk, change, and the promotive effects of Early Head Start. Early Childhood Research Quarterly; 24, 289-305

Bagnato, S. J. (2007). Authentic assessment for early childhood intervention: Best practices. New York: The Guilford.

Blachman, B. A. (2007). The importance of phonological awareness and decoding for early literacy instruction. Dalam Barbara J. Guzzetti (ed). Literacy for the new millennium, vol 1. Westport: Praeger Perspective.

Bjorklund, D. F. (2005). Children's thinking. Cognitive Development and Individual Differences. Belmont, CA: Thomson Wadsworth Learning. 
Bruns, D. B. \& Pierce, C. D. (2007). Let's read together: Tools for early literacy development for all young children. Young Exceptional Children, 10(2), 210.

Crim, C., Hawkins, J. T., Rosof, H. B., Copley, J., \& Thomas, E. (2008). Early Childhood Educators' Knowledge of Early Literacy Development. Issues in Teacher Education, 17(1), 17-30.

Farver, J. M., Nakamoto, J., \& Lonigan, C. J. (2007). Assesing preschoolers"s emergent literacy skills in English and Spanish with Get ready to read. Annual of Dyslexia, 57: 161-178

Friend, A., DeFries, J.C., Olson, R.K., Pennington, B., Harlaar, N., Byrne, B., ..... \& Keenan, J.M. (2009). Heritability of high reading ability and its interaction with parental education. Behavior Genetic, 39:427436.

Gonzalez. J. E., Goetz, E. T., Hall, R. J., Payne, T., Taylor, A. B., Kim, M., \& McCormick, A. S. (2009). An evaluation of Early Reading First (ERF) preschool enrichment on language and literacy skills. Reading Writing. Doi:10.1007/s11145-0099212-8.

Invernizzi, M., Landrum, T. J., Teichman, A., \& Townsend, S. (2010). Increased implementation of emergent literacy screening in pre-kindergarten. Early Childhood Education Journal, 37(6), 437-446.

Justice L., M. \& Kaderavek, J. (2002). Using shared storybook reading to promote emergent literacy, Teaching Exceptional Children, 34(4), 8-13.
Laakso, M. L., Poikkeus, A. M., Eklund, K., \& Lyytinen, P. (2004). Interest in early shared reading: its relation to later language and letter knowledge in children with and without risk for reading difficulties, first language. Diunduh dari http://www.fla.sagepub. com/cgi/content/refs/24/3/323.

Lonigan, C. J. (2006). Development, assessment, and promotion of pre literacy skills. Journal of Early Education and Development, 17 (1), 91-114

Lonigan, C. J., Anthony , J. L., Bloomfield, B. G., Dyer, S. M., \& Samwel, C. S. (1999). Effects of two shared-reading interventions on emergent literacy skills of at-risk preschoolers. Journal of Early Intervention, 22(4), 306-322.

Marvin, C. A. \& Ogden, N. J. (2002). A Home literacy inventory: Assessing young children's context for emergent literacy. Young Exceptional Children, 5(2), 1-10.

Molfese, V. J., Modglin, A. A., Beswick, J. L., Neamon, J. D., Berg, S. A., Berg, C. J., \& Molnar, A.. (2006). Letter knowledge, phonological processing, and print knowledge: Skill development in nonreading preschool children. Journal Learning Disability, 34(4), 296-305.

Moorea, A. C., Akhterb, S., \& Abouda, F.E . (2008). Evaluating an improved quality preschool program in rural Bangladesh. International Journal of Educational Development, 28, 118131.

Papalia, D. E., Olds, S. W., \& Feldman R. D. (2001). Human development. Boston: McGraw Hill. 
Philips, B. M., Clancy-Menchetti, J., \& Lonigan, C. J. (2008). Successful phonological awareness instruction with preschool children: Lessons from classroom. Topics in Early Childhood Special Education, 28(1), 3-17.

Reese, L., Garnier, H., Gallimore, R., \& Goldenberg, C. (2000). Longitudinal analysis of the antecedents of emergent Spanish literacy and middle-school English reading achievement of Spanish-Speaking students. American Educational Research Journal, 37(3),633-662.

Sarbidi. (2011). Geomorfologi dan wilayah pantai kota Semarang. Makalah. (Tidak dipresentasikan). Proceeding Dampak Timbal Balik Antara Pembangunan Kota dan Perumahan di Indonesia dan Lingkungan Global.

Soderman, A. K., Gregory, K. M., \& McCarty, L. T. (2005). Scaffolding emergent literacy: A child-centered approach for preschool through grade 5. Boston: Pearson education, Inc.

Torr, J. \& Scott, C. (2006). Learning special words: Technical vocabulary in the talk of adults and preschoolers during shared reading. Journal of Early Research, 4(2); 153-167.
Tracey, D. H. \& Morrow, L. M. (2006). Lenses on reading: An introduction to theories and models, New York: The Guilford Press.

Whitehurst, G. J. (2001). The NCLD Get Ready to Read! Screening tool technical report. Diperoleh dari http://www.getreadytoread.org /image /GRTR_\%Screen_Tech.pdf.)

Whitehurst, G. J. \& Lonigan, C. J. (2001). Emergent literacy: Development from prereaders to reader. Dalam S. B. Neuman \& Dickinson (eds), Handbook of early literacy research (pp. 11-28). New York: Guilford Press

Widjaja, V. \& Winskel, H. (2004). Phonological awareness and word reading in a transparent orthography: Prelimenary findings on Indonesian. Proceedings on the $10^{\text {th }}$ Australian International Conference on Speech Science \& Technology

Wilson, S. N. \& Lonigan, C. J. (2009). An evaluation of two emergent literacy screening tools for preschool children. Annual of Dyslexia, 59(2), 115-131. 